DOI https://doi.org/10.18551/rjoas.2018-09.14

\title{
SEM ANALYSIS OF INNOVATIVE BEHAVIOR INFLUENCE TOWARDS HUMAN RESOURCE PERFORMANCE
}

\author{
Sedyowidodo Urip*, Fortunisa Ananda, Djamaris Aurino Rilman Adam, \\ Novianti Mirsa Diah \\ University of Bakrie, Jakarta, Indonesia \\ *E-mail: urip.sedyowidodo@bakrie.ac.id
}

\begin{abstract}
Objective of the study is to analyze how much influence entrepreneurial orientation has towards corporate performance on which organizational learning becomes the moderating variable. This verificative descriptive study conducted surveys in the national state-owned enterprises. The data analysis method was Structural Equation Model/SEM. In general, the indicators of entrepreneurial orientation were commitment to novelty, risk-taking and being proactive. The indicators of organizational learning was learning process in individual, group or organizational level, while those of corporate performance were customer satisfaction, financial condition, internal business process, learning/improvement. The finding showed that entrepreneurial orientation had significant influence towards corporate performance.
\end{abstract}

\section{KEY WORDS}

Entrepreneurial orientation, corporate performance, organizational learning, business.

Effective Human Resource (HR) management strategy is one vital requirement amidst increasingly complex, dynamic and global-oriented business. Many predicted that HR strategy that emphsizes on creativity and innovation is the most effective one to anticipate fierce business. Davila, Epstein \& Shelton (2015) argued that creativity and innovationoriented strategy encourages company to create new products and eventually becomes a market leader. Selecting business strategy should ideally be followed with HR strategy and corporate culture that stimulate creativity and innovation. Professional human resources, ones that are skillful, committed, innovative, open-minded and flexible, are the key to successful implementation of business strategy. Synergy between business and HR strategy as well as corporate culture is really important for business performance. This study discusses relationship between creative thinking and innovative behavior towards HR performance in achieving corporate goals.

In order to survive and grow, a company depends upon profit instead of mere luck. Other factors are hard-work, problem-solving ability and ability to take advantage of business opportunity. Problem-solving ability and ability to take advantage of business opportunity are derived from creativity of human resources, which is ability to come up with new ideas and methods to solve issues and seize business opportunity. Innovation refers to an ability to apply new ideas or solutions. In short, it can be said that creativity = thinking new things, while innovations $=$ doing new things.

Innovation and creativity are two pivotal traits an individual should have. Creativity, where an idea is derived from, plays an important strategic role in this discussion. It is expected that high creativity results in more innovation. However, very few people are exploring their their creative potentials.

Many believe that process and innovation begins with creativity. Innovative employees help companies developing their competitive advantage. Well-organized business model alone does not guarantee successful business; indicator of successful a company is careful implementation of the business plan.

Very few companies encourage their staffs to be creative and innovative. The significant role of creative and innovative human resource towards business performance encouraged the researchers analyze influence of creative-thinking and innovative behavior towards performance of non-financial staffs. 


\section{THEORETICAL FRAMEWORK AND HYPOTHESIS}

Conceptual Definition of Creativity and Innovation. Neither public or business sector in Indonesia paid attention towards creativity. Many people associated creativity with children. Very few associated it with adult. As a matter of fact, creativity is one of the keys to face increasingly competitive business and industrial sectors.

Discussing the definition of creativity, literatures mentioned several aspects of creativity, such as creating new products, generating new ideas, combination and association between various disciplines, shifting from conventional perspective to modern one, making breakthrough, generating a lot of ideas, and using different perspectives. The definitions of creativity are as follows:

- Capability to develop new concepts and relationship, analyze subject from new perspectives and develop new combinations from two or more existing concepts (Mc. Coy, 2012);

- Creativity refers to combining theoretical concepts (knowledge) from different fields of study or discipline in order to generate new and more improved concepts (M.A. West, 1997: 1).

West (1997: 2) defined innovation as intentional introduction and implementation of a task, team or organization, from new ideas, processes, products, or procedures for the task, team, or organization to benefit the aforementioned task, team, or organization.

Therefore, innovation starts from an idea, from either internal or outside a company to create and apply new concepts and eventually influence or benefit the company. The most important elements of innovation are ideas, implementation and utilization. An individual should draw a line between innovation and invention or creativity. Discovery is a creative process that includes knowledge and information to create new products. On the other hand, innovation is a longer process as it begins with discovering an idea, and then is followed by introduction of the idea and transforming it into applicable and profitable methods or product.

West (1997: 31) stated that behavioral component and attitude are closely related to individual tendency to select particular set of action. In conclusion, this behavioral component is an action component of attitude. An individual may be friendly, warm, agressive, hostile or apathetic towards another individual or use various methods to interact with other individuals.

Innovative Behavior. In terms of anatomy and psychology, human being is pretty similar between each other. These anatomical and psychological similarities lead to similar behavior between individuals. Innovative individual will maintain his or her individual compensation and learn to combine his or her knowledge to that of compay where he or she works.

In addition, innovative behavior increases intellectual capacity of an individual from "know what" to "care why." When all individuals in an organization has reached this "care why" stage, the organization becomes intelligent corporation. Tunggal (2012) defined intelligent corporation as company that is able to develop its competitive advantage in sustainable manner from its knowledge and service-based activities while relying on its intellectual assets. Innovative behavior of an individual is represented by his or her participation in all activities related to innovation. This innovative behavior is pivotal as innovative work has more risks than routines. Successful innovation is a simple and focused innovation. It is specific, clear, well-organized and applicable. In the long run, successful innovation creates new customers and market.

Combining various definitions of creative and innovative behavior, the authors defined creative and innovative behavior as "related attitude and behavior that creates innovative employees".

West (1997)'s Concept for Developing Creativity in Organization. Developing creativity and innovation in organizatios mean applying a proactive and well-organized strategy to generate creative and innovative processes. It means attracting, developing and supporting creativity of individuals in an organization. It means to induce constructive conflict and various perspectives in modern and heterogenous organizations to produce creative and innovative ideas. 


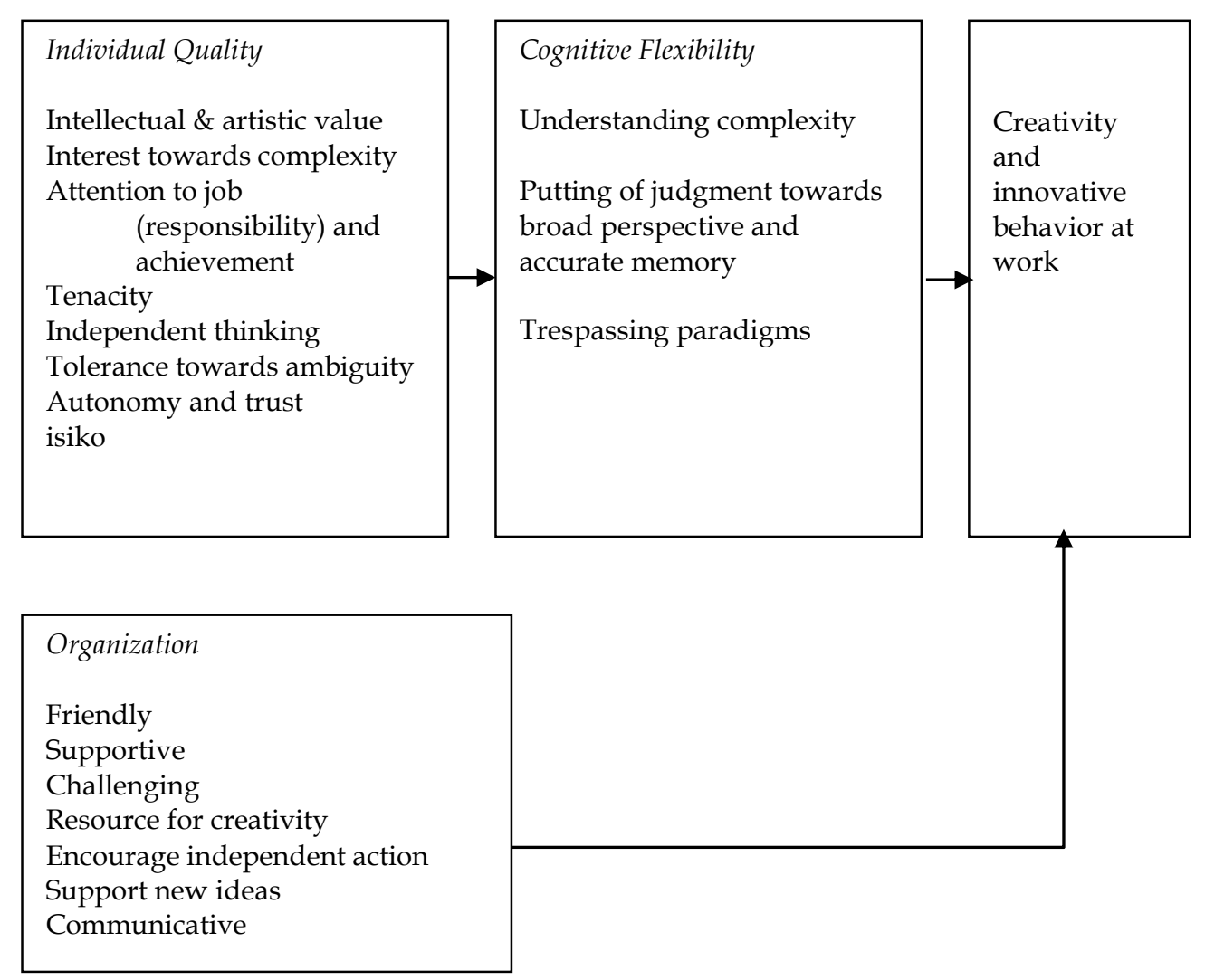

Figure 1 - Characteristics of Creative Individuals and Their Working Environment (West, 1997)

In general, leaders of organization do not pay close attention to customer strategy (who the targets are; what value works in an organization?) or realize and understand how much important HR development strategy or Human Capital is . In the current organizational and economic development like today, more particularly in value creation, human capital and other intangible capital become dominant commodity.

Framework of Thinking and Hypothesis. Recently, a lot of companies can afford expensive, modern engine and equipment but they do not hire skillful employees to run those machinery. It is difficult for company who lost its competent employees to recover and therefore, companies should pay close attention to HR strategy. HR strategy supports implementation of corporate strategy which later is translated into HR activities, policies and programs that help achieveing corporate strategy.

HR plays strategic role in a company and HR startegy is manifested into HR activities that develop value creation without putting aside cost efficiency (Becker, Huselid \& Ulrich, 2011: 59; Dharma \& Sunatrio, 2011). HR policy, process and practice company carries out should represent high performance work system, which means HR activity is conducted based on CEO policy and existing system and is expected to influence other HR programs.

Identifying creative thinking and innovative behavior is one of the strategic roles of HR because it focusses on HR productivity. Strategic behavior of employee refers to innovative or productive behavior of employees and this has direct influence towards implementation of corporate strategy (Becker, Huselid \& Ulrich, 2011:20; Peniwati, 2011).

Priority of strategic HR development program is developing creative thinking and innovative behavior of employees without putting aside efficiency (Becker, Huselid \& Ulrich, 2011:61; Dharma \& Satrio, 2011).

Based on the elaboration, combination of effective management system and appropriate HR strategy can foster intrapreneur skills of employees. It is expected that development of intrapreneurial environmennt encourage creativity and innovation and improve HR performance. 


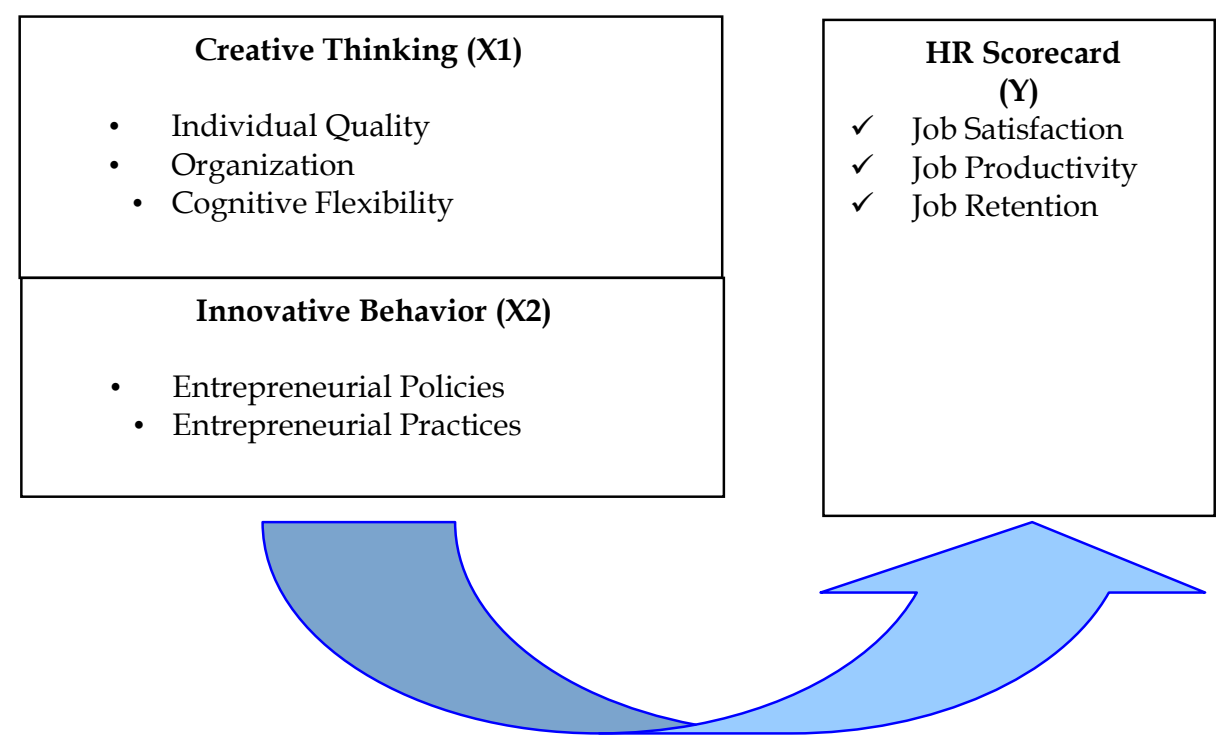

Figure 2 - Framework of Thinking

Hypotheses. Based on the framework, the hypotheses are as follows:

- Creative thinking has influence towards innovative behavior;

- Inovative behavior has direct influence towards HR performance.

Subject of the Study. The subject of this study is PT XYZ (which later was referred to as the company) located in Jakarta. The company focuses on Engineering Procurement Construction (EPC).

The respondents were 3 employees of Engineering, Procurement and Construction division. The respondents filled out questionnaire discussing management practices in the company. As an addition, the respondents described their job satisfaction, retention (loyality, leave intention and attendance) and productive behavior (development of moral capacity, creativity and innovation).

Self appraisal performance was the indicator to observe and measure productive behavior of the respondents. Even though the self appraisal performance has been used widely, it may reduce accuracy of the result. In order to obtain additional information and cross-check the data from the questionnaire, the authors interviewed several Heads of EPC divisions where the respondents worked.

Objects of the study were creative thinking and innovative behavior of the EPC employees as well as performance of non-financial HR. These objects became variables of the study and were analyzed using SEM (Structural Equation Model).

\section{METHODS OF RESEARCH}

Objective of the study is to analyze influence of creative-thinking and innovative behavior towards performance of EPC employees using HR Scorecard approach. It means this study was a descriptive study. In addition, the study aimed to provide justification on the influence of creative-thinking and innovative behavior towards performance of EPC employees. Therefore, this study was also categorized as verificative research or explanation research. Based on its types, this study used Explanatory Survey Method, a survey of which objective is to elaborate relationship between variables (Sugiyono: 2014). The type of investigation was causal relationship, or to find out how much influence (degree) independent variable has towards dependent variable.

The analysis unit was performance of Engineering Procurement and Construction division of the company.

Population and Sampling Method. The population was 500 employees of EPC division of the company. 
To determine number of sample, the authors used Slovin's formula (as cited in Yamane, 1967:99) as follows:

$$
\mathrm{n}=\mathrm{N} /\left(\mathrm{N}(\mathrm{d})^{2}+1\right)
$$

Where: $\mathrm{N}=$ population or EPC division employees in the company; $\mathrm{N}=$ sample or the EPC division employees selected as samples; $D$ = level of confidence.

Based on the formula, the total samples were at least 223 employees. Sampling technique the authors used was Probability Sampling.

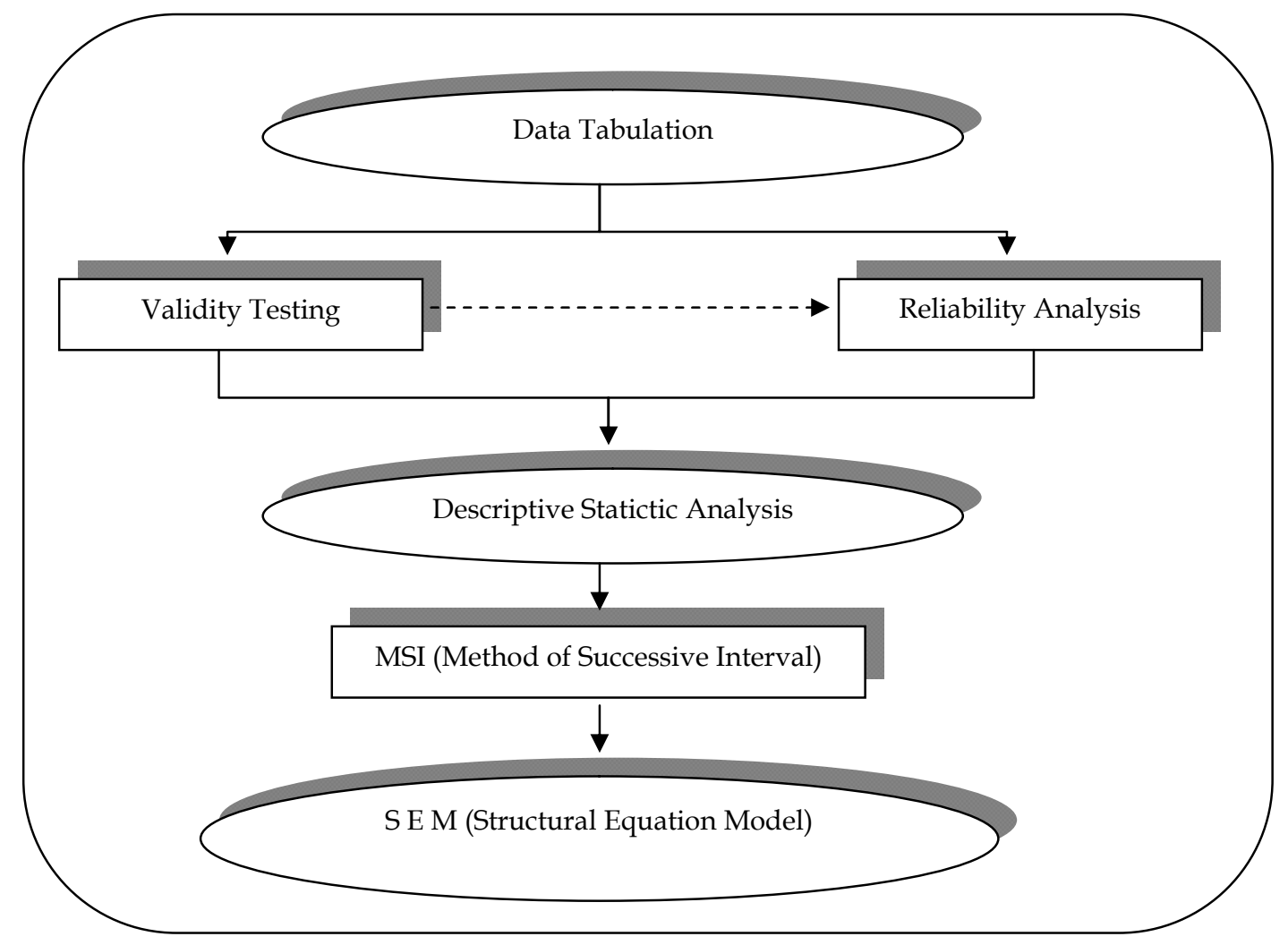

Figure 3 - Data Analysis Procedures

The data analysis method was SEM (Structural Equation Model), or a method to analyze multivariate, dependence data by combining factorial analysis and path analysis in order to justify particular theories or model. Based on the limitation, three major characteristics of SEM are as follows:

1). SEM is compact combination of two multivariate data analysis, namely factorial and path analysis;

2). Instead of developing a model, SEM provides empirical justification or confirmation towards certain model or theoretical analysis;

3). SEM develop simultaneous confirmation of two major components, namely measurement or structural model.

Figure 4 showed a model with 3 (three) latent variables, namely 2 (two) exogenous variables $\left(\xi_{1}, \xi_{2}\right)$ and 1 (one) endogenous variable $(n 1)$. $\xi_{1}$ was manifested or measured based on three manifests or variables $\left(X_{1}, X_{2}\right.$, and $\left.X_{3}\right)$, while $\xi_{2}$ was manifested based on two manifests or variables $\left(\mathrm{X}_{4}\right.$ and $\left.\mathrm{X}_{5}\right)$.

The endogenous variable $(\eta 1)$ was manifested nased on three manifests or variables (Y1, Y2 and Y3).

Having developed a complete path diagram, the authors converted the diagram into equations, namely equations for exogenous latent variables, endogenous laten variable and structural equation. 


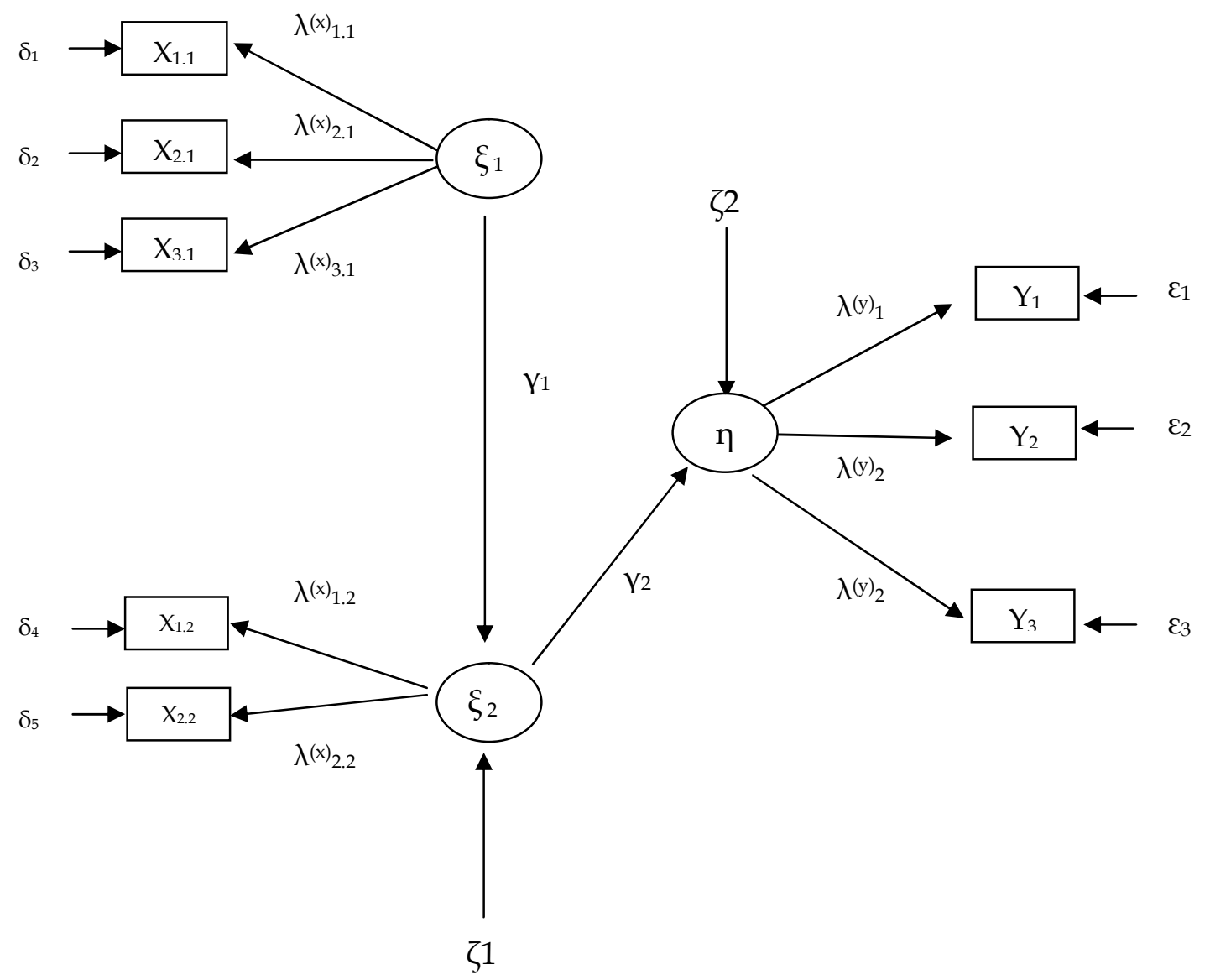

Figure 4 - Basic Model (Complete Path Diagram) of SEM

Equation to measure the exogenous latent variable $\left(\xi_{1}\right)$ :

$$
\begin{aligned}
& X_{1.1}=\lambda^{(x)}{ }_{11} \xi_{1}+\delta_{1} \\
& X_{2.1}=\lambda^{(x)}{ }_{21} \xi_{1}+\delta_{2} \\
& X_{3.1}=\lambda^{(x)}{ }_{31} \xi_{1}+\delta_{3}
\end{aligned}
$$

Equation to measure the exogenous latent variable $\left(\xi_{2}\right)$ :

$$
\begin{aligned}
& X_{1.2}=\lambda^{(x)}{ }_{12} \xi_{2}+\delta_{4} \\
& X_{2.2}=\lambda^{(x)}{ }_{22} \xi_{2}+\delta_{5}
\end{aligned}
$$

Equation to measure the endogenous latent variable $(\eta)$ :

$$
\begin{aligned}
& Y_{1}=\lambda^{(y)}{ }_{1} \eta+\varepsilon_{1} \\
& Y_{2}=\lambda^{(y)}{ }_{1} \eta+\varepsilon_{2} \\
& Y_{3}=\lambda^{(y)}{ }_{3} \eta+\varepsilon_{3}
\end{aligned}
$$

Structural model between the latent variables:

$$
\begin{aligned}
& \xi_{2}=\gamma_{1} \xi_{1}+\zeta_{1} \\
& \eta=\gamma_{2} \xi_{2}+\zeta_{2}
\end{aligned}
$$

Model Evaluation. In this stage, the model was evaluated based on several goodness of fit. Kusnendi (2005: 26) postulated some elements describing why these goodness of fit indexes can be used to analyze a model: 
- $\chi^{2}$ (statistical Chi-square). A model is fit when $\chi^{2}$ is low. In this study, low $\chi^{2}$ resulted in level of confidence higher than $95 \%$;

- $\quad \mathrm{NFI}$ (Normed Fit Index). A model is fit when NFI $\geq 0.90$;

- RMSEA (The Root Mean Square Error of Approximation). A model is fit when RMSEA $\leq 0.08$.

Table 1 - Fit Indexes

\begin{tabular}{|c|c|}
\hline$\chi^{2}$ Fit Index & Recommended Score (lower estimation) \\
\hline Significanced Probability & $\geq 0.05$ \\
\hline NFI & $\geq 0.90$ \\
\hline RMSEA & $\leq 0.08$ \\
\hline
\end{tabular}

Having finsihed the goodness of fit analysis, the following procedures were unidimensional analysis and reliability testing. Unidimensionality refers to an assumption used to analyze reliability of a model by showing that the model is in one dimension and indicators used have goood fit. On the other hand, reliability refers to internal consistency of a construct showeing to which degree each indicator indicates general latent construct/factor. There are two types of reliability testing Construct Reliability and Variance Extracted. The minimum acceptable requirement for reliability testing is $C-R \geq 0.7$.

The second type of reliability testing is Variance Extracted (V-E) which shows variance of indicators extracted from latent variable. High Variance Extracted (V-E) shows that indicators have been able to reprsent latent variable well. The minimum acceptable $\mathrm{V}-\mathrm{E}$ score for reliability testing is $\mathrm{V}-\mathrm{E} \geq 0.5$.

\section{RESULTS AND DISCUSSION}

Influence of Creative Thinking and Innovative Behavior towards Non-Financial HR Performance. This section discussed result of SEM analysis on influence of creative thinking $\left(\xi_{1}\right)$ and innovative behavior $\left(\xi_{2}\right)$ towards non-financial HR performance $(\eta)$.

There are two requirements to run an analysis using Structural Equation Modeling (SEM), namely (1) data should have at least interval scale of measurement and (2) data obtained from questionnaire should have ordinal scale and later be transformed into interval scale using Method of Successive Interval (MSI) after scoring. The authors used Method of Successive Interval (MSI) to transform the information on creative thinking $\left(\xi_{1}\right)$, innovative behavior $\left(\xi_{2}\right)$ and non-financial HR performance $(\eta)$ into interval (see Appendix for complete information about the three variables). The following procedure was estimation of total score for each sub-variable using Structural Equation Modeling (SEM) and Lisrel 8.3 software.

In SEM analysis, data normality test was conducted using Test of Multivariate Normality, of which objective is to describe whether or not the data have met multivariate normal distribution. It was conducted using Lisrel-Prelis 2.30 software in which based on the statistical analysis was 270.247 and p-value was 0.000 . Since p-value was lower than 0.05 , Ho was rejected (data with normal distribution and it can be concluded that the data did not have multivariate normal distribution. In this study, SEM and matrix of correlation were used to describe influence of the independent variables towards the dependent one (coefficient).

Based on SEM analysis towards the data obtained from 321 samples, the authors were able to obtain estimated coefficient showing influence between the variables. Figure 5 showed path diagram of the structural model.

In the SEM analysis, several criteria were used to analyze whether or not the model have met goodness of fit measures (Hair, 2008: 659). Table 2 showed comparison between the data and those criteria. 


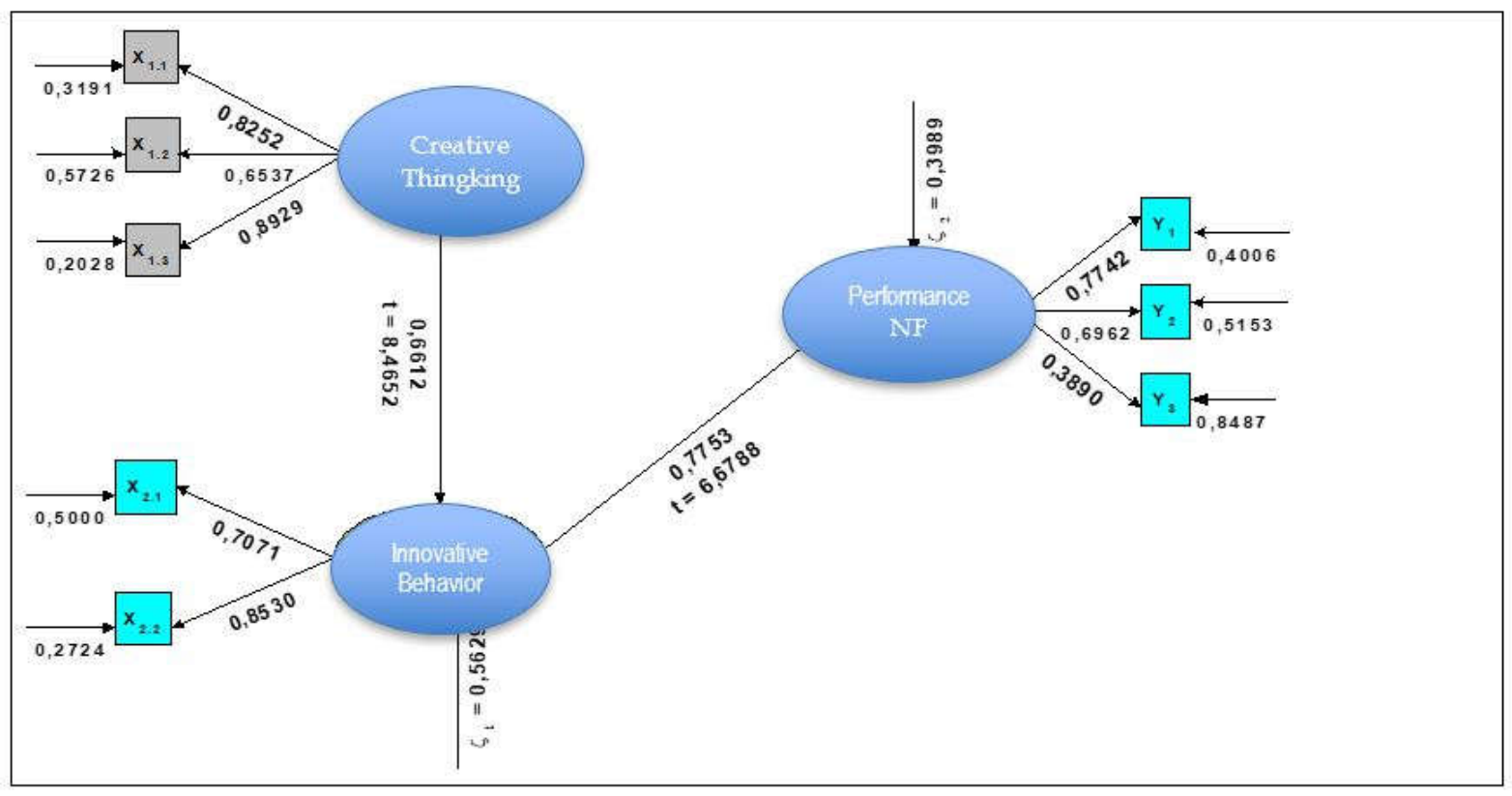

Figure 5 - Path Diagram of the Structural Model on "the Influence of Creative Thinking $\left(\xi_{1}\right)$ towards Innovative Behavior $\left(\xi_{2}\right)$ and Influence of Innovative Behavior $\left(\xi_{2}\right)$ towards Non-Financial HR Performance $(\eta)$ "

Table 2 - Comparison based on criteria of Goodness of fit measures

\begin{tabular}{|l|l|}
\hline USN National Model Goodness of Fit Criteria & Result of Analysis \\
\hline test is not significant $(p$-value $>0.05)$ & test was significant $(p$-value $=0.000)$ \\
\hline NFI is lower than 0.90 & NFI $=0.7997$ \\
\hline RMSEA was low (RMSEA between 0.05 and 0.08 can be accepted) & RMSEA $=0.194$ \\
\hline
\end{tabular}

Source: Hair (1998:659).

These scores showed that testing was significant. ( $p$-value $<0.05)$. Based on the second criteria, NFI (Normed Fit Index) of the model was 0.7997 or below the maximum acceptable score of NFI (0.90). Furthermore, RMSEA of the model was 0.194.

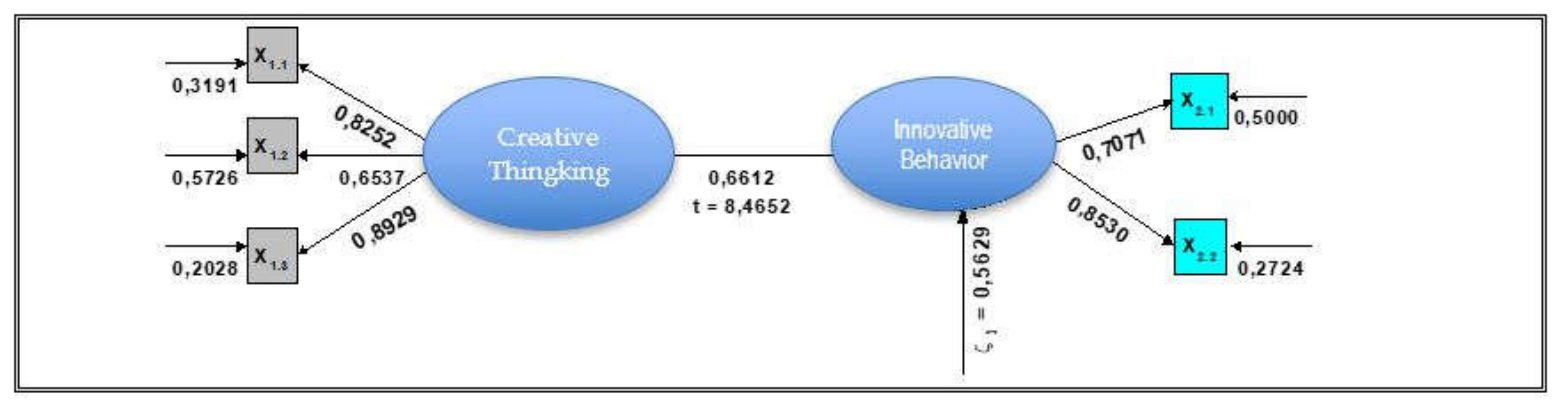

Figure 6 - Path Diagram of the Structural Model on "the Influence of Creative Thinking $\left(\xi_{1}\right)$ towards Innovative Behavior $\left(\xi_{2}\right)$ "

Based on the three Goodness of Fit Criteria, the model describing influence of creative thinking and innovative behavior towards HR performance did not meet the Goodness of fit measures. However both validity and reliability testing showed that all items in the questionnaire were valid and reliable. It is predicted that the model cannot meet the Goodness of Fit criteria due to the following factors, namely:

- The study used only one instrument that did not represent the supervisor and employees separately; 
- Based on the data analysis, the coefficient describing influence of creative thinking towads innovative behavior was 0.6612 and thus, influence of creative thinking towards innovative behavior was $0.6612^{2}=0.4371$. In conclusion, creative thinking influenced $43.71 \%$ of the innovative behavior while the remaining $56.29 \%$ was influenced by other factors. In the model, these other factors were classified as errors. These errors had higher contribution but unfortunately were not involved as indicators of the variables.

Figure 6 showed path diagram of the structural model and estimated coefficient showing influence between the variables based on SEM analysis.

Based on Figure 6, it can be seen that coefficient showing the influence of creative thinking towards innovative behavior was 0.6612 and t-value was 8.4652 .

Table 3 - Hypothesis Testing on Partial Influence of Creative Thinking towards Innovative Behavior

\begin{tabular}{|c|c|c|c|c|c|}
\hline Hypothesis & $\begin{array}{c}\text { Path } \\
\text { Coefficient }\end{array}$ & $\mathrm{t}_{\text {value }}$ & $\mathrm{T}_{\text {table }}$ & & Conclusion \\
\hline $\begin{array}{c}\text { Creative thinking has influence } \\
\text { towards innovative behavior }\end{array}$ & 0.6612 & 8.4652 & 1.965 & $\begin{array}{c}\text { Sig } \\
\text { Test }\end{array}$ & $\begin{array}{c}\mathrm{H}_{0} \text { was rejected; creative thinking } \\
\text { influences innovative behavior }\end{array}$ \\
\hline
\end{tabular}

Source: Primary Data.

The table showed analysis towards the first hypothesis, the influence of creative thinking towards innovative behavior. Based on significant testing, $t$-value was higher than $t-$ table (1.965). When level of confidence was $95 \%$, it can be concluded that creative thinking has significant influence towards innovative behavior.

Figure 7 showed path diagram of the structural model and estimated coefficient showing influence between the variables based on SEM analysis.

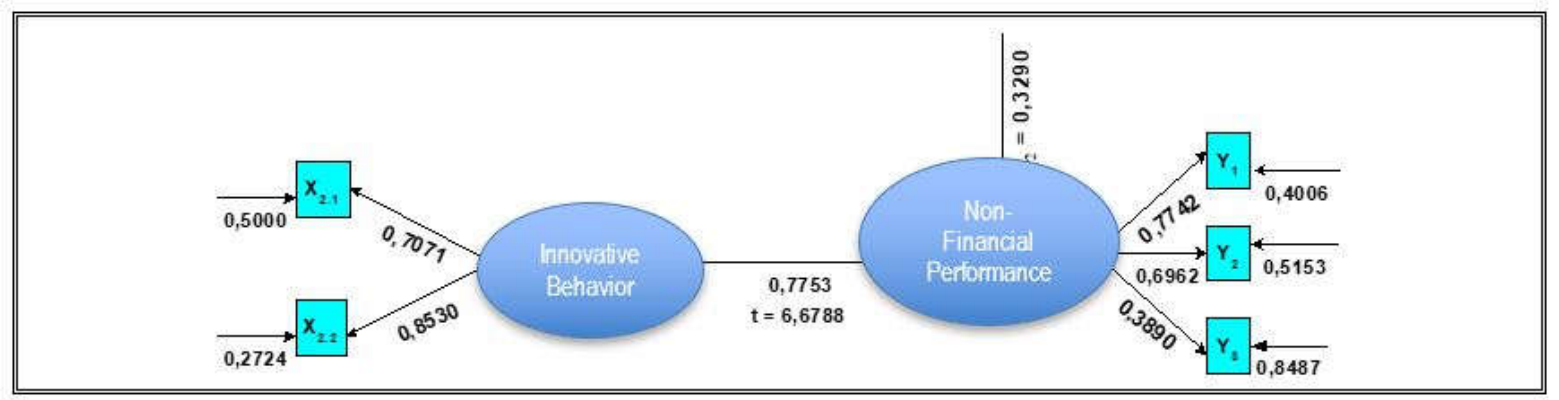

Figure 7 - Path Diagram of the Structural Model on "the Influence of Innovative Behavior $\left(\xi_{2}\right)$ towards Non-Financial HR Performance $(\eta)$ "

Figure 7 showed that coefficient showing influence of innovative behavior towards nonfinancial HR performance was 0.7753 and t-value was 6.6788 .

Table 4 - Hypothesis Testing on Partial Influence of Innovative Behavior towards Non-Financial HR Performance

\begin{tabular}{|c|c|c|c|c|c|}
\hline Hypothesis & $\begin{array}{c}\text { Path } \\
\text { Coefficient }\end{array}$ & $\mathrm{t}_{\text {value }}$ & $\mathrm{T}_{\text {-table }}$ & Decision & Conclusion \\
\hline $\begin{array}{c}\text { Innovative behavior } \\
\text { influences non-financial HR } \\
\text { performance }\end{array}$ & 0.7753 & 6.6788 & 1.965 & Sig Test & $\begin{array}{c}\mathrm{H}_{0} \text { was rejected; innovative behavior } \\
\text { has influence towards non-financial } \\
\text { HR performance }\end{array}$ \\
\hline
\end{tabular}

Source: Primary Data.

The analysis showed that innovative behavior had influence towards non-financial HR performance since t-value was higher than t-table (1.965). When level of confidence was $95 \%$, it can be concluded that innovative behavior has significant influence towards nonfinancial HR performance. 


\section{DISCUSSION OF RESULTS}

HR Performance $(\eta)$. HR performance $(\eta)$ was measured based on 3 sub-variables, namely job satisfaction $\left(\mathrm{Y}_{1}\right)$, job productivity $\left(\mathrm{Y}_{2}\right)$ and job retention $\left(\mathrm{Y}_{3}\right)$. Table 5 showed loading factors of each sub-variable.

Table 5 - Loading Factor of HR Performance (Latent Variable)

\begin{tabular}{|c|c|c|c|c|c|}
\hline HR Performance Sub-variables & Notation & Loading Factor & t-value & $\mathrm{R}^{2}$ & Error Variance \\
\hline Job Satisfaction $\left(\mathrm{Y}_{1}\right)$ & $\lambda_{Y_{1}}$ & 0,7742 & 8.6586 & 0.5994 & 0.4006 \\
\hline Job Productivity $\left(\mathrm{Y}_{2}\right)$ & $\lambda_{Y_{2}}$ & 0.6962 & 8.6725 & 0.4847 & 0.5153 \\
\hline Job Retention $\left(\mathrm{Y}_{3}\right)$ & $\lambda_{Y_{3}}$ & 0.3890 & 5.6498 & 0.1513 & 0.8487 \\
\hline Construct Reliability & $=$ & 0.6621 & & \\
\hline \multicolumn{2}{|l|}{ Variance extracted } & $=$ & 0.4118 & & \\
\hline
\end{tabular}

Source: Primary Data.

Based on Table 5, Construct Reliability of HR performance is 0.6621 or lower than the lowest requirement of 0.70 . It means the sub-variables of HR performance do not have Good Fit.

Based on the questionnaire, job retention has high score $(85.1 \%)$ but the observation and survey shows that there is no correlation between length of work and job satisfaction. Chi-square statistical analysis reported that there is no correlation between the respondents' length of work and their job satisfaction.

Therefore, it can be concluded that there is no difference in the respondents' job satisfaction towards the length of work-related aspects in PT. XYZ.

Variance Extracted of non-financial HR performance was 0.4118 or lower than the minimum standardized requirement of 0.50 . It means only $41.18 \%$ of the sub-variables were involved in the construct (HR performance).

Based on Table 5, job satisfaction $\left(Y_{1}\right)$ has higher loading factor compared to the other sub-variables.

Creative Thinking $\left(\xi_{1}\right)$. Creative thinking $\left(\xi_{1}\right)$ consists of 3 sub-variables, namely individual quality $\left(X_{1.1}\right)$, organizational performance $\left(X_{1.2}\right)$ and cognitive flexibility $\left(X_{1.3}\right)$. Table 6 shows loading factors of these sub-variables.

Table 6 - Loading Factor of Creative Thinking (Latent Variable)

\begin{tabular}{|l|l|l|l|l|l|}
\hline Creative Thinking Sub-variables & Notation & Loading Factor & t-value & $\mathrm{R}^{2}$ & Error Variance \\
\hline Individual Quality $\left(\mathrm{X}_{1.1}\right)$ & $\lambda \times 1.1$ & 0.8252 & 16.5374 & 0.6807 & 0.3193 \\
\hline Organizational Performance $\left(\mathrm{X}_{1.2}\right)$ & $\lambda \times 1.2$ & 0.6537 & 12.2489 & 0.4274 & 0.5726 \\
\hline Cognitive Flexibility $\left(\mathrm{X}_{1.3}\right)$ & $\lambda \times 1.3$ & 0.8929 & 18.4204 & 0.7972 & 0.2028 \\
\hline Construct Reliability & $=$ & 0.8371 & & & \\
\hline Variance extracted & $=$ & 0.6352 & & & \\
\hline
\end{tabular}

Source: Data Analysis.

Based on Table 6, t-value of each sub-variable of creative thinking was higher than 1.965. It shows that these sub-variables are significant indicators of creative thinking.

Table 6 showed that Construct Reliability of creative thinking is 0.8371 or higher than the minimum requirement of 0.70 . Variance Extracted of creative thinking was 0.6352 (higher than the minimum requirement of 0.50 ). It means $63.52 \%$ variance of the sub-variables was involved in the construct (creative thinking).

Table 6 indicated that cognitive flexibility $\left(X_{1.3}\right)$ has higher loading factor compared to two others sub-variable. In other words, cognitive flexibility is dominant factor of creative thinking.

The finding is in line with Michael A. West (1997:17) that a creative employee has always used different perspectives/paradigms for solving problems at work. 
Innovative Behavior ( $\left.\xi_{2}\right)$. Innovative behavior consists of 2 sub-variables, entrepreuneurial policies $\left(\mathrm{X}_{2.1}\right)$ and entrepreuneurial practices $\left(\mathrm{X}_{2.2}\right)$. Table 7 showed loading factors of these sub-variables.

Table 7 - Loading Factor of Innovative Behavior (Latent Variable)

\begin{tabular}{|l|l|l|l|l|l|}
\hline Innovative Behavior Sub-variables & Notation & Loading Factor & t-value & $\mathrm{R}^{2}$ & Error Variance \\
\hline Entrepreuneurial policies $\left(\mathrm{X}_{2.1}\right)$ & $\lambda \times 2.1$ & 0.7071 & 11.8464 & 0.5000 & 0.5000 \\
\hline Entrepreuneurial practices $\left(\mathrm{X}_{2.2}\right)$. & $\lambda \times 2.2$ & 0.8530 & 8.6586 & 0.7276 & 0.2724 \\
\hline Cunstruct Reliability & $=$ & 0.7591 & & & \\
\hline Variance extracted & $=$ & 0.6138 & & & \\
\hline
\end{tabular}

Source: Data Analysis.

Based on Table 7, t-value of innovative behavior is higher than 1.965 which shows that all of the sub-variables are significant to develop innovative behavior.

Tabel 7 shows that Cunstruct Reliability of innovative behavior is 0.7591 or higher than the minimum requirement if 0.70 . This score means that the construct is accepted and the sub-variables of innovative behavior have Goodness Fit.

Variance Extracted of innovative behavior is 0.6138 . It means the construct (innovative behavior) has involved $61.38 \%$ of the sub-variables.

Furthermore, entrepreuneurial practices $\left(X_{2.2}\right)$ has higher loading factor compared to the other sub-variable. It means entrepreuneurial practices is a dominant factor of innovative behavior.

Influence of Creative Thinking towards Innovative Behavior. Based on the Structural Equation Modeling, creative thinking has significant influence towards innovative behavior. Coefficient showing the significant influence of creative thinking towards innovative behavior is 0.6612 and thus, degree of influence is $0.6612^{2}=0,4371$. In other words, creative thinking influences $43.71 \%$ of innovative behavior while other factors outside this study influences the remaining $56.29 \%$.

Percentages of individual quality and cognitive flexibility are $77.4 \%$ and $76.6 \%$ respectively. These show that the employees are creative. In conclusion, the company hires employees with high creative and innovative potentials.

Table 8 - Respondents' Data Distribution on Entrepreneurial Practices

\begin{tabular}{|c|c|c|c|c|c|c|c|c|c|c|}
\hline \multirow{3}{*}{ Entrepreneurial Practices } & \multirow{3}{*}{$\begin{array}{l}\text { No. } \\
\text { Item }\end{array}$} & \multicolumn{8}{|c|}{ Respondents' Data Distribution } & \multirow{3}{*}{$\begin{array}{l}\text { Average } \\
\text { Score }\end{array}$} \\
\hline & & \multicolumn{2}{|l|}{4} & \multicolumn{2}{|l|}{3} & \multicolumn{2}{|l|}{2} & \multicolumn{2}{|l|}{1} & \\
\hline & & & $\%$ & $f$ & $\%$ & $f$ & $\%$ & $f$ & $\%$ & \\
\hline \multirow{2}{*}{ Plan for making innovation } & 41 & 58 & 18.6 & 185 & 59.3 & 61 & 19.6 & 8 & 2.6 & 2.99 \\
\hline & 42 & 56 & 17.9 & 215 & 68.9 & 39 & 12.5 & 2 & 0.6 & $(74.8 \%)$ \\
\hline \multirow{2}{*}{ Managerial vision focused on opportunity } & 43 & 89 & 28.5 & 211 & 67.6 & 12 & 3.8 & 0 & 0.0 & 3.15 \\
\hline & 44 & 49 & 15.7 & 234 & 75.0 & 25 & 8.0 & 4 & 1.3 & $(78.7 \%)$ \\
\hline \multirow{2}{*}{$\begin{array}{l}\text { Developing entrepreneurship skills of the } \\
\text { employees }\end{array}$} & 45 & 9 & 2.9 & 112 & 35.9 & 170 & 54.5 & 21 & 6.7 & 2.48 \\
\hline & 46 & 14 & 4.5 & 171 & 54.8 & 116 & 37.2 & 11 & 3.5 & $(61.9 \%)$ \\
\hline \multirow{2}{*}{$\begin{array}{l}\text { Management willingness to listen to } \\
\text { employees' aspiration }\end{array}$} & 47 & 2 & 0.6 & 132 & 42.3 & 169 & 54.2 & 9 & 2.9 & 2.40 \\
\hline & 48 & 2 & 0.6 & 128 & 41.0 & 173 & 55.4 & 9 & 2.9 & $(60.0 \%)$ \\
\hline \multicolumn{10}{|c|}{ Average Total Score on Entrepreuneurial Practices } & $\begin{array}{l}2,75 \\
(68.9 \%)\end{array}$ \\
\hline
\end{tabular}

Source: Primary Data.

Influence of Innovative Behavior towards Non-Financial HR Performance. The Structural Equation Modeling shows that innovative behavior has significant influence towards non-financial HR performance. Coefficient of innovative behavior towards HR performance was 0.7753 and thus, degree of influence was $\left(\rho_{Y X_{2}}^{2}\right) 0.7753^{2}=0.6011$. In other words, innovative behavior influences $60.11 \%$ of HR performance while other factors outside this study influences the remaining $39.89 \%$.

Based on Table 8 , showing the indicators of innovative behavior, percentage of developing entrepreneurial skills of the employees is $61.9 \%$ or low; as the result, the 
company should conduct more programs of which objective is to develop entrepreneurial skills of the employees. As an addition, percentage of manager's willingness to listen to employee's aspiration is also low (60.0\%). It is predicted that management has pivotal role in developing creativity and innovative behavior of the employees. These percentages contribute to total average percentage of Entrepreneurial Practices, which is $68.9 \%$.

The average percentage of Entrepreneurial Practices $(68.9 \%)$ is lower than average percentage of Entrepreneurial Policies (75.3\%). Innovative employees have positive impact towards corporate performance and therefore, management should provide wider opportunity for the employees to get involved in decision-making process.

\section{CONCLUSION}

Based on the questionnaire, observation and interview, the company has not been able to foster creativity or innovative behavior of its employees. It does not encourage the employees to come up with new ideas or conduct programs that help the employees improving their entrepreneurial skills. At last, the management provides very little time to listen to the employees' aspiration.

Creative thinking has influence towards innovative behavior. Creative thinking consists of three sub-variables, namely individual quality, organizational performance, and cognitive flexibility. Among these three sub-variables, cognitive flexibility has the largest contribution towards innovative behavior of the employees. Furthermore, innovative behavior consists of 2 sub-variables, Entrepreuneurial Policies and Entrepreneurial Practices. Based on the analysis, Entrepreneurial Policies has higher score compared to Entrepreneurial Practices. It means Entrepreneurial Practices is a dominant factor that influences development of innovative behavior.

\section{RECOMMENDATIONS}

Management should consider employees as strategic assets and therefore, start developing and apply programs derived from entrepreneurial policy consistently in order to improve cognitive flexibility, creative thinking and innovative behavior of their employees;

Management should provide opportunity for employees to realize their ideas. This opportunity creates balance between entrepreneurial policies and entrepreneurial practices and eventually improve job performance;

Since the model (the influence of creative thinking and innovative behavior towards HR non-financial performance) has yet to meet the Goodness of fit measures, future researchers should modify the variables, develop questionnaire for both supervisors and employees or develop correlation model between the variables.

\section{REFERENCES}

1. As'ad, M. 2013. Psikologi Industri. Yogyakarta: Penerbit Liberty.

2. Becker, B. E., Huselid, M. A., \& David, U. B. (2011). The HR Scorecard: Linking People, Strategy and Performance. Boston: Harvard Business School Press.

3. Cartwright, R. (2013). Pribadi Entrepreneur. Jakarta: Penerbit Prestasi Pustakaraya.

4. Davila, T., Epstein, M. J., \& Robert, S.(2015). Making Innovation Work. New Jersey: Wharton School Publishing.

5. Gaynor, G. H.(2012). Innovation by Design: What It Takes to Keep Your Company on The Cutting Edge. New York: AMACOM.

6. Hubeis, M. (2005). Manajemen Kreativitas dan Inovasi dalam Bisnis. Jakarta: Hecca Mitra Utama.

7. Irwanto (2002). Psikologi Umum. Jakarta: Penerbit PT Prenhallindo.

8. Joreskog, K. G.(1993). Structural Equation Modeling with the SIMPLIS Command Language. New Jersey: Lawrence Erlbaum Associate, Hillside. 
9. Kaplan, R. S. \& Norton, D.P. (2004). Strategy Maps. Boston: Harvard Business School Publishing.

10. Kusnendi (2005). Konsep Dan Aplikasi Model Persamaan Struktural SEM Dengan Program Lisrel 8. Bandung: Badan Penerbit JPE, FPIPS, Universitas Pendidikan Indonesia.

11. Luecke, R. (2013). Managing Creativity and Innovation. Boston: Harvard Business School Publishing.

12. Lupiyoadi, R. (2014). Entrepreneurship from Mindset to Strategy. Jakarta: Lembaga Penerbit Fakultas Ekonomi Universitas Indonesia.

13. McCoy, C.(2012). Why Didn't I Think of That? Surabaya: Ikon Teralitera.

14. Oemarjoedi, K. (2013). Pendekatan Cognitive Behaviour dalam Psikoterapi. Jakarta: Penerbit Creative Media.

15. Overton, R. (2012). Are You an Entrepreneur? Singapore: Wharton Books (S) Pte Ltd

16. Petty, G. (2012). How to be Better at Creativity-Memaksimalkan Potensi Kreatif. Jakarta: Penerbit PT Elex Media Komputindo.

17. Rampersad, H. K.(2015). Total Performance Scorecard. Jakarta: Penerbit PT Gramedia Pustaka Utama.

18. Safaria, T. (2015). Creative Quotient. Yogyakarta: Platinum Diglossia Media Baru.

19. Siregar, S. (2014). Statistik Terapan untuk Penelitian. Jakarta: Penerbit PT Grasindo.

20. Sugiyono. (2014). Statistik Nonparametris. Bandung: Penerbit CV Alfabeta.

21. West, M.A. (1997). Developing Creativity in Organizations. The British Psychological Society; Leicester, UK.

22. Winardi, J.(2015). Entrepreneur dan Entrepeneurship. Jakarta: Prenada Media.

23. Wycoff, J. (2012). Menjadi Super Kreatif Melalui Metode Pemetaan-Pikiran. Bandung: Penerbit Kaifa PT Mizan Pustaka.

24. Wycoff, J. (2015). Are You an Entrepreneur? Retrieved from http://www.jpmi.or.id on July $30^{\text {th }}, 2018$. 